\title{
Towards a personology of a hospitality professional
}

\author{
Maria Gebbels, University of Greenwich
}

Ioannis S. Pantelidis and Steven Goss-Turner, University of Brighton

\begin{abstract}
This article provides new insights on what makes hospitality professionals by proposing a new framework: the personology of a hospitality professional. This framework is based on an in-depth analysis of the literature on self-efficacy, career inheritance and career commitment. Understanding the key characteristics of people who choose hospitality as their profession is of great importance to an industry that provides one in ten jobs worldwide, and in the United Kingdom alone employs 4.49 million people. The need for quality employees who consider hospitality a long-term career is of paramount importance. Stakeholders often perceive the hospitality industry as a hardworking and low-paying one. If employers wish to retain existing talent and also attract new talent, they need to have a better understanding of their employees' key characteristics. The proposed personology will enable hospitality stakeholders to identify key indicators that aid in a deeper understanding of what constitutes a hospitality professional. This can facilitate the interview process and yield better recruitment and selection outcomes whilst contributing to the scarcity of knowledge on what being a hospitality professional entails.
\end{abstract}

\section{Keywords}

hospitality careers

self-efficacy

career commitment 
career inheritance

personology

professionalism

\section{Introduction}

The hospitality industry is a fast-growing industry. According to the World Travel and Tourism Council (WTTC) one in ten jobs are provided by the global tourism industry (WTTC 2017). In the United Kingdom alone it is the fourth largest employer, employing 2.9 million people (Oxford Economics 2015; UKHospitality 2019). For employees, the industry offers an array of career opportunities, both nationally and internationally. However, the social perception continues to draw attention to its negative characteristics. In the western context hospitality employment is considered as temporary, poorly paid and of low status (Baum 2015; Mooney et al. 2016). Hospitality organizations often rely on a contingent workforce employed under flexible conditions, on a part-time or seasonal basis, which are factors contributing to high staff turnover (Hjalager and Andersen 2001). Talent shortage within the global tourism industry continues to be the most critical issue for human resource management (WTTC 2015).

The industry is associated with long unsociable hours and low monetary rewards, and as pointed out by Cockburn-Wootten (2012), has a reputation of being a hostile work environment (cf. Poulston 2008; Maxwell et al. 2010), making it difficult to appeal to, recruit and retain a skilled workforce, including individuals who undertake hospitality management degrees. The hospitality industry is also known for job movement or vocational mobility, either with one employer or across a variety of organizations (Baum 2015, Mooney et al. 2016). With a growing number of hospitality degrees and available courses, the need for educated and committed staff should not be an issue (Birkett 2008; Walmsley 2011). 
However, a requirement for an additional 200,000 managers - between 2007 and 2017 - to join the hospitality workforce was established (Hospitality Guild 2013; People 1st 2013). A report by People 1st identifies a need of 66,000 more managers by 2020 (People 1st 2013). Research indicates that one of the challenges that hospitality businesses have been facing is '[g]etting the right staff with the right skills in the right place at the right time' (Haven-Tang and Jones 2008: 353), which is also linked with this industry relying on human capital to deliver a high quality of service (Cheng and Wong 2015). This becomes more of a pertinent issue as the industry is also attempting to alleviate other factors that impact on customeremployee interaction, such as 'low entry barriers into the industry, lifestyle businesses, weak management skills, low pay, high labour turnover, lack of qualifications and training, decreasing labour pools, invisible career paths, and deskilling' (Haven-Tang and Jones 2008: 353). An often-cited solution has been the application of the most appropriate managerial strategy (Brotherton and Wood 2000), such as offering employees flexible working hours, job sharing or continuing development opportunities (Michel et al. 2013). Yet, the successful hospitality business is dependent on its employees to deliver exceptional service and as the industry continues to grow the need for qualified and educated workforce has become more apparent (Kaufman and Ricci 2014). The industry is still at its infancy in terms of offering a clear career system with well-outlined career paths, which means that many employees may have irrelevant education, consider this industry as a stepping stone to another career or enter the industry only to leave for more rewarding economic activities (Hjalager and Andersen 2001).

More importantly, as noted by Cheng and Wong (2015), the hospitality industry, unlike other industries, relies heavily on human capital and the quality of its employees, and thus the performance of a business is strongly dependent on getting this human element of any hospitality business right. Furthermore, as highlighted by Baum (2015: 205) 'the quality 
of the people in the workplace can make a real and positive difference to business outcomes'. Therefore, the recognition of employees' skills and professionalism is key to ensuring a stable workforce and increased career longevity among existing employees (Mooney et al. 2016). Thus, professionalism will be examined in this conceptual article as an overarching discourse defined through the lens of attitudinal dimensions, whilst emphasizing the importance of employing a qualified and skilled workforce (Lee 2014). Personology, a concept established in personality psychology, which claims that only through a systematic and an in-depth study of each individual is it possible to claim any knowledge of human personality, becomes an overarching framework for understanding the key characteristics of a hospitality professional (Murray 1981; Stolorow 2012).

The research question that this article aims to answer - what makes a hospitality professional? is one that resonates not only amongst researchers but has further significance for the hospitality industry (Lee 2014). The way the question is structured suggests that the notion of a hospitality professional is already an existing reality, informed by the recent shift of applying the discourse of professionalism to less traditional occupations. Based on the review of literature on professionalism and a critical understanding of self-efficacy, career inheritance and career commitment (Bandura 1986; Inkson 2004; Meyer et al. 2002), and their unique interaction, the authors lay foundations for the personology of a hospitality professional. This is further informed by the understanding of professionalism as consisting of attitudinal dimensions referring strictly to the characteristics of an individual (Hall 1968; Cheng and Wong 2015). As further explained by Lee (2014: 140) 'in this dimension, professionalism refers to a set of individual values, a behavior orientation, and a belief system which advances the personal expertise and social status of individuals' occupations'. Therefore, by proposing dispositional traits of a hospitality professional, the authors also aim to make a contribution to the theoretical understanding of professionalism (Lee 2014). 
This article begins by discussing previous research on professionalism, by first defining this concept and exploring its origins, and then examining the notions of a hospitality professional. The literature on the concepts of career commitment, career inheritance and self-efficacy is then critically reviewed, with a purpose of establishing its merits and possible limitations within the hospitality context. The article concludes with a number of possible avenues for further research including a framework of a personology of a hospitality professional informed by the three interdisciplinary concepts, which is considered the original contribution of this conceptual article to the understanding of what makes a hospitality professional. The knowledge of this personology will equip hospitality managers with more reliable selection outcomes during the recruitment and selection process, and enable them to employ the most suitable candidate who will take ownership of their roles and responsibilities, thus benefiting, not only his or her career but also the employing organization.

\section{Understanding professionalism}

Despite the many efforts to propose effective solutions such as supporting staff in developing their own careers and increasing their career satisfaction (Barnett and Bradley 2007; Kong et al. 2011), the hospitality industry continues to struggle with staff retention and rising turnover (Mullen 2016; Cassel et al. 2018). Yet the industry continues to be the fourth biggest employer in the United Kingdom (British Hospitality Association 2017) and therefore the way to approach this significant issue is to focus on understanding those who choose this industry as their profession. However, it is necessary to highlight at this point that due to the contingent nature of the hospitality work, low entry barriers and absence of specific educational qualifications (Haven-Tang and Jones 2008), many individuals work in the hospitality industry not by choice but rather due to lack of other alternatives. Furthermore, the 
often transient and temporary nature of the work available in this industry, which suits workers who are looking for mere employment rather than a career, is inconsistent with the notion of professionalism and career commitment. These aspects related to the nature of hospitality work, whilst of great significance to the wider discourse on hospitality employment, are beyond the scope of this article.

To depict the typology of a hospitality professional, the term personology and professionalism are applied. Personology aids in understanding individuals' behaviour through the analysis of how the past, present and future influence their personality (Schultz and Schultz 2009). This is based on Murray's (1981) approach to personality and personality assessment. The concept of professionalism is rather ambiguous and its definition has been differentiated based on its application to occupational settings (Evetts 2011). Traditionally associated with classical professions such as engineering and the sciences (Cheng and Wong 2015), the understanding of the term professionalism has undergone some significant changes since its original appearance in the field of sociology in the 1930s (Hussey et al. 2010).

Early research on professionalism emphasized 'professional values of collegiality, occupational identity and the application of standards of behaviour' (Noordegraaf 2007; Hussey et al. 2010: 4; Cheng and Wong 2015). In the 1950s and 1960s it was considered fundamental that a long period of training was required to acquire the knowledge and expertise of particular professions (Wilensky 1964), with the focus on regulating professional groups and ensuring that their members shared similar traits (Hussey et al. 2010; Cheng and Wong 2015). The research in the 1970s centred on the process of professionalization monitored by measuring if occupational groups have the required competencies or traits (Swailes 2003). More recent understanding of professionalism is that it is a multi-dimentional concept (Noordegraaf 2007; Lee 2014) and it is recognized as an ideology; an agreement is 
yet to be reached as to what those dimensions are (Hussey et al 2010; Lee 2014; Cheng and Wong 2015).

Qualifications and development, competence and commitment are just some of the traits that a professional needs to be equipped with to practice as an accountant, for instance (Burgess 2011). Haven-Tang and Jones (2008) propose that small businesses should focus on adopting strategies that illustrate employee commitment to promote motivation and staff retention, such as offering existing employees additional training. Every industry requires its employees to be equipped with a set of qualities, such as personality traits or soft skills, to fit in well within the overall demands of the job role. The same can be said for the hospitality industry, which requires its employees to acquire, develop and exhibit skills associated with dealing with high psychological pressures (Niu 2010). This is particularly true in customer-facing roles in the hospitality industry, which are not only physically but also emotionally challenging. Being compassionate and kind, instilling trust, having confidence and the ability to lead and be knowledgeable are just some examples of soft and hard traits that a hospitality professional needs to be equipped with (Dhir 2013).

As the term 'professionalism' has been used interchangeably with 'profession' and 'professional', Helsby (1996) clarified these two key terms to reflect the increasing sophistication of consumers (Cheng and Wong 2015). 'Being a professional' carries with it status, reward and public recognition, whilst 'behaving professionally' confers dedication, codes of behaviour and strong service ethic (Helsby 1996). Moreover, Cockburn-Wootten (2012) identified that being a professional is a label that carries with it a particular meaning of the working conditions for the organization and for the employee, such as the benefits of an autonomous workforce who identify with their work, and better working conditions or pay. 
As a result of societal changes, professionalism has been extended to other disciplines, beyond lawyers and doctors (Cheng and Wong 2015), and thus its impact on the tourism and hospitality industry has been receiving increased academic attention (cf. Mak et al. 2011; Burgess 2011; Ko 2012). Although the focus of research has been on different perspectives with which to explore professionalism, as noted by Pizam (2007), hospitality workers should particularly be able to demonstrate appropriate attitudes. Among such attitudes are taking the initiative, willingness to accept challenges, enthusiasm and energy, working hard, resilience, integrity, and maintaining a professional appearance (Wang 2013). In their research on the Danish tourism industry, Hjalager and Andersen (2001: 115) discuss the development of professional culture through the employment of 'personnel trained specifically for the sector', which also highlights the many existing interpretations of the term professionalism (Hussey et al 2010).

As it is widely acknowledged that professionalism is a prerequisite for one's success (cf. Hussey et al. 2010) and continues to be critical for organizational success (Swailes 2003), the knowledge of how to make a successful career is necessary to enable individuals to make informed choices. Suh et al. (2012) identified six dimensions of core competencies required by managers in the hospitality industry, which are hospitality skills, interpersonal skills, supervisory skills, food and beverage management skills, leadership and communication skills. Sisson and Adams (2013) concluded that interpersonal skills, communication, ethics and leadership are the most important soft competencies for success in hospitality management, whilst technical or cognitive knowledge of the product or service are the secondary hard competencies. Hussey et al. (2010) identified multiple dimensions of a professional applicable to a tourism professional, which are altruism, code of ethics, body of knowledge and specialist skills and expertise. Formal education was also highlighted as a contributor towards achieving professionalism (Hussey et al. 2010). In their research both 
Paraskevas (2001) and Chen et al. (2005) conclude that professionalism of the hospitality workforce acts as a condition for success, whilst how psychologically meaningful their work is becomes a known measure of employee success (Sullivan 1999). This further highlights the importance of encouraging employees to attain and develop personal skills and competencies such as continuous learning, acceptance of uncertainty, autonomy, self-awareness and selfefficacy (Ballout 2009). Furthermore, Cheng and Wong's (2015: 122) exploratory study of perceptions of staff and managers working in the hotel industry in Hong Kong identified 'eight elements of professionalism, namely, passion, sensitivity, and open-mindedness to new trends, team-oriented attitude, competence and skills, emotional self-control, professional ethics, leadership by example, and perfectionism'.

Cassel's et al. (2018) research on career paths in the Swedish hospitality sector concluded that high mobility and regular job changes, together with internal and practical knowledge of the industry, are part of the normative assumptions that shape hospitality careers. Kong et al. (2011) devised a scale for hotel career management consisting of the following dimensions career appraisal and advice, a career development programme and career training. As opposed to the current conceptualization of a career as concerning the individual who is not bounded to an organization or an employer (Cassel et al. 2018), this research has sought to engage hotel operators and human resource managers in assisting their employees in achieving successful hospitality careers through the use of the aforementioned scale (Kong et al. 2011). Driven by a limited number of previous studies that have rarely tested career competencies, Wang (2013) develops a career competency model for a successful career in the food and beverage department in international tourist hotels. Wang (2013) identified career development, career adjustment and control, workplace attitude, and communication and networking as the four key dimensions of career competency that can assist people in enhancing and satisfying their career developmental needs. However, according to Bharwani 
and Jauhari (2013), compared with other sectors, hotels choose their workforce on the basis of their competencies and task proficiency or specific technical expertise and job aptitude as opposed to their individual characteristics. Following the principles of personology, which holds 'as its basic premise the claim that knowledge of human personality can be advanced only by the systematic, in-depth study of the individual person' (Stolorow 2012: 471), the authors consider it necessary to understand the individual person and the role that they play by contributing to the dispositional as opposed to trait-based characteristics or core competencies all widely researched, as illustrated by the examples discussed above. Such knowledge will also aid in determining the internal factors that impact on one's behaviour (Baumgartner 2002). Thus, in this article professionalism is defined through the lens of attitudinal dimensions as knowledge pursuance, self-management, a sense of calling and customer orientation (Lee 2014).

Thus, as an ever-changing industry, individuals who choose a career in hospitality have to be not only aware of its demands and challenges, but learn to manage and rely on their own capabilities to develop specialized skills and professional relationships, and achieve success in their personal and work life (Niu 2010). Although a number of studies have been conducted to determine the skills required to be successful in a hospitality career (cf. Tesone and Ricci 2006; Ruetzler et al. 2011; Kwok et al. 2012), further knowledge is necessary to understand the traits of hospitality professionals. Therefore, in this article, the focus is not on the structural aspects of an occupation such as the establishment of a training school, or a formation of a professional association (Hall 1968; Cheng and Wong 2015). Instead the aim is to advance knowledge of the attitudinal dimension of professionalism, with current examples being the feeling of autonomy at work and a sense of calling (Cheng and Wong 2015). To achieve this, the authors critically examine the three concepts - career 
commitment, career inheritance and self-efficacy to gain insights on what makes a hospitality professional.

\section{Hospitality career commitment}

Despite increased attention paid to the subject of commitment (Meyer et al. 1993), historically the work on career commitment has received the least attention, with the focus being directed towards the concepts of job and employee commitment (Aryee and Tan 1992; Meyer et al. 1993; Goulet and Singh 2002).

This concept has been first operationalized and measured by Blau $(1985,1988)$, who defined career commitment as ‘one's attitude towards one's profession or vocation' (Blau 1985: 278). This term is often used as an umbrella concept to describe commitment to one's career, one's profession and one's occupation (Cooper-Hakim and Viswesvaran 2005). In this article these three forms of work-related commitment are not considered synonymous. Instead career commitment is defined as a psychological state of a relationship between an individual and solely his or her career, and is reflected in an ability to cope with challenges whilst seeking career goals (Aryee and Tan 1992). Historically, the notion of commitment has been conceptualized in relation to organizations, in a form of three-component model of commitment (Meyer and Allen 1984; Meyer et al. 1993). Affective commitment reflects an emotional attachment to, identification with and involvement in the organization; continuance commitment is the perceived cost linked to leaving the organization; and normative commitment denotes a perceived obligation to remain in the organization (Meyer et al. 2002).

Each component is used to explain different mind-sets that direct an individual towards a certain course of action. These are the mind-set of desire, perceived cost and obligation, meaning affective, continuance and normative commitment, respectively (Meyer and Herscovitch 2001). All three forms of commitment are of an affective nature (Meyer et 
al. 2002). The emotional attachment to one's career is very significant in helping to decide whether one desires to stay or leave the chosen career field, and remains the strongest among the other two dimensions of commitment (Meyer et al. 1993; Meyer et al. 2002). Although originally the three-component model of commitment referred to organizational commitment, they are considered relevant to the concept of career commitment. Career commitment can be affected, enhanced and changed by many factors. The more educated employees are, and the higher their job status, the higher the level of career commitment (Goulet and Singh 2002). Employees are also more inclined to remain in their job and continue in their chosen career. This corresponds with conclusions made by Colarelli and Bishop (1990), Ladkin (2002) and Vance (2006), who proposed that better educated employees are more interested in their career development, which results in higher career commitment. Other factors that enhance levels of career commitment include initial challenging work experience, positive professional development experiences, supportive organizational environment and interesting work (Sullivan et al. 1998). Career experiences of individuals will also differ depending on age, gender, individual differences, country of birth, attitude towards life and job satisfaction (Cherniss 1991; Sullivan et al. 1998; Niu 2010). Inner characteristics of an individual, such as self-worth and resilience, can influence commitment to a career, and how an individual positions himself or herself within the chosen career and who, or what, the individual is committed to (Goulet and Singh 2002).

A significant body of academic research supports the hospitality industry statistics indicating a low retention rate in the hospitality industry indicative of low or lack of career commitment. The following examples also indicate that the concept of career commitment is often explored in relation to hospitality graduates' career intentions. According to King et al. (2003), $50 \%$ of the respondents left the hospitality industry within three-five years after graduating, and the number of graduates entering the hospitality industry had decreased over 
the years. A follow-up study in 2003 indicates that only $48 \%$ of hospitality graduates remained in the industry (O'Leary and Deegan 2005) and 68\% of respondents moved jobs at least once, which supports the high staff turnover rates in the industry (O'Leary and Deegan 2005). According to Johns and McKechnie (1995) and Barron et al. (2007), only half of hospitality graduates have chosen a career in that industry in the United Kingdom. In contrast, a longitudinal research by Walsh and Taylor (2007) identified that almost 54\% of hotel administration graduates from Cornell University, between 1987 and 2002, worked directly in the industry. Some of the reasons for this high retention rate included challenging work, new skills development and promotional opportunities. Yet research by Ladkin and Weber (2010) about professionals working in the convention and exhibition industry showed a high level of career commitment that enhanced their overall performance. The main premise of career commitment is that employees are more interested in long-term career promotion opportunities and their loyalties belong to their chosen careers, rather than to the employing organization or employer. Furthermore, in the ever-changing world, individuals are required to be versatile, responsible and in charge of their career development, characteristics also associated with a protean career, or in other words adaptable and changeable career (cf. Hall 2004).

As previously discussed, the transient nature of work in the hospitality industry is in contrast with the concept of commitment, which has been illustrated by the above research examples on low levels of commitment in the hospitality industry. Yet, career commitment implies an affective relationship between an individual and his or her chosen career, and one aspect of that relationship is the ability to deal successfully with career-related challenges (Aryee and Tan 1992). Together with challenging work experience, positive professional development experiences and supportive organizational environment (Sullivan et al. 1998), the hospitality professional with high career commitment relies less on organizations and more on 
themselves to achieve secure careers and fulfil their long-term career goals. Thus career commitment is the first dispositional characteristic of the proposed personology of a hospitality professional.

\section{Hospitality career inheritance}

Although there are many ways to conceptualize the term career, Inkson (2004: 100) argues that a career 'in some way and to a varying extent, is inherited from the 'families' of which we are part'. Therefore the careers that individuals follow are likely to be influenced by the type of the family one was born into. Career as inheritance is one of the nine metaphors proposed by Inkson (2004) and it illustrates how people understand and interpret careers (Inkson 2007). Significant for this article is that career as inheritance allows considering an individual's past and how it shapes one's life, and most importantly career. It also examines the characteristics one was born with, such as the genetic make-up, sex or race, and the changes and additions during the period leading up to the start of a career (Inkson 2004, 2007). This theory explains that, as children develop their interests and aspirations and start to align their career choices with their developing self-concepts, they also become more aware of their family's career inheritance and how it can affect their future career decisions (Gottfredson 2002; Inkson 2007). They also begin to eliminate vocational options if incompatible with their evolving self-image (Swanson and Fouad 2010). This developmental perspective on career is based on Gottfredson's (2002) theory of circumscription, compromise and self-creation, whereby the choice of a career is a 3-stage, developmental process, which starts during childhood (Gottfredson 1996). For instance, if born to a family of hoteliers, some people may find making career choices challenging because they may feel constrained by and unable to remove that career inheritance. This, in turn, may stop them from becoming the proactive shapers of their own career paths (Inkson 2004, 2007), which 
implies that being a professional, in this case a hospitality professional, may be a byproduct of following a career that does not fully encompass one's career identity.

The concept of career inheritance can also be framed in a number of ways - social class, gender, ethnicity, education and family background can become part of the inheritance difficult to get away from (Inkson 2004). Yet with the development of self-knowledge, individuals who are free agents able to choose and pursue career goals begin to also take charge of their life decisions. Thus, career inheritance should not be treated as an unnecessary burden; rather career choices and decisions should be placed in the hands of the individual making them. Knowledge of one's career inheritance should empower the decision-maker to either accept or reject this legacy by practicing the proactive career behaviour (Inkson 2004).

Career inheritance states that in the midst of making career decisions, individuals who are able to either accept or reject their career legacy become the most empowered (Inkson 2004). This leads to the second plausible characteristic of a hospitality professional, which implies that one's career inheritance can work either in favour or against one's career choices, and potentially career commitment. The significant component of career inheritance is an individual's awareness of their self-concept and their self-knowledge, which guide them in determining their future career decisions.

The concept of career inheritance, with its focus on continuing a particular career legacy, can be further expanded on by incorporating the concept of hospitableness, where the term hospitality is understood as '[...] a ubiquitous aspect of human behaviour' (Blain and Lashley 2014: 1). Being hospitable, which implies providing for other's basic needs through the host and guest interaction, is a characteristic that according to Telfer (2000) is part of the term hospitableness. She further explains that 'hospitableness is [...] the trait possessed by hospitable people' who feel the need to share their homes or provisions with others (Telfer 2000: 39). Yet it goes beyond the scope of this particular interaction and implies that offering 
hospitality does not require any repayment or other forms of reciprocity, and is therefore of an altruistic nature (Blain and Lashley 2014). Such genuine hospitality, considered as an individual trait and one of the six dimensions of core competencies by Suh et al. (2012), can be applied to providing hospitality as part of the professional demands of working in the hospitality industry and beyond. Thus, career inheritance helps us to understand hospitality professionals as individuals for whom hospitality is both a passion and a facilitator of future career choices. As soon as one associates oneself with being a true hospitality professional, this trait remains part of one's identity. Therefore, providing hospitality becomes a second nature to a hospitality professional as it is an inescapable part of their professional life, informed by principles of career inheritance.

\section{Hospitality self-efficacy}

Family members and friends, peers and others in the community can influence the development of one's career preferences. For instance, in their seminal work on parents as role models, also the conceptual basis for career inheritance, Goodale and Hall (1976) concluded that parents have a great deal of influence on students' career-related choices. Parents' interests and preferences for children's college may act as a mediator between parents' background and educational and career aspirations for high school students (Goodale and Hall 1976). Yet the degree to which one takes opinions of others into consideration will differ, depending on whether belonging to a family or a community is more important than independent decision-making (Law 1981). Such level of autonomy corresponds with the attitudinal aspect of professionalism discussed earlier (Cheng and Wong 2015) and may also suggest that taking charge of one's career choices is what makes individuals more likely to succeed in their chosen pursuit. 
Thus, having beliefs in one's own capabilities is at the core of perceived self-efficacy, which implies that cognitive, self-regulatory and self-reflective processes are principal to human adaptation and change (Bandura 1986; Burke et al. 2009). The concept of self-efficacy, central to the social cognitive theory by Bandura (1986), is rooted in human agency and can be defined as 'people's level of motivation, affective states, and actions based more on what they believe than on what is objectively true' (Bandura 1977: 2). Thus, as an expression of human agency, self-efficacy beliefs empower people to take charge of their lives, in particular their choices and actions, whilst perseverance associated with self-efficacy is likely to lead to increased performance and productivity (Cherian and Jacob 2013). It has been considered, among other motivational constructs, as the more consistent predictor of behavioural outcomes (Graham and Weiner 1996). Self-efficacy, and the social cognitive theory, emphasize the cognitive-person variables, which enable people to exercise control over their lives and influence the perception of personal agency (Lent et al. 2002a, 2002b).

Therefore individuals who perceive their self-efficacy as high are more likely to achieve success in their career pursuits, are also more committed to their careers and use the perceptions of adequate capabilities to succeed and develop specialized skills and professional relationships (Niu 2010). It is this belief in the self and in one's own capabilities that shifts the emphasis onto agency as the more significant factor in guiding people's actions, as opposed to the structural influences. Self-efficacy has been considered 'one of the most important ingredients - perhaps the most important ingredient - in the recipe for success' (Maddux 2002: 277). Whilst it helps individuals to self-regulate their behaviour by cognitive, motivational, affective and selection processes, self-efficacy beliefs develop from four distinct sources (Bandura 1977, 1997, 1998). Previous accomplishments achieved on one's own are the first and most powerful source, which increases individuals' beliefs in the future success (Bandura 1986; Usher 2009). Modelling one's own behaviour on that of 
successful others can also significantly impact on performance and become a source of aspiration and motivation (Bandura 1986, 1998). The third source, encouragement and verbal persuasion, increases beliefs in one's own capabilities and the 'you can do it' catch phrase is one of the most common and effective ways of verbal support and encouragement. The fourth source of self-efficacy requires using physical and emotional states to judge capabilities, strength, vulnerability to dysfunction and learn how to act on them to achieve the most desired outcomes (Bandura 1986, 1997).

Based on Bandura's self-efficacy theory, Hackett and Betz (1981) introduced career decision self-efficacy, which is defined as having confidence in the ability to effectively engage in tasks and activities related to making career decisions (Taylor and Betz 1983; Choi and Kim 2013). It is a forward-facing construct, which relates to 'beliefs one has about one's potential in the future' (Higgins et al. 2008: 209). The research employing self-efficacy in hospitality studies is still rather limited. Niu's (2010) findings of the effects of employees' self-efficacy on the levels of career commitment in the food service industry suggest that high self-efficacy indicates higher levels of career commitment. The study by Choi and Kim (2013) into career preparation behaviour of hospitality and tourism students concludes that self-efficacy, among other factors, impacts on the relationship between students' learning and career behaviour. As self-efficacy expresses one's confidence to effectively engage in and execute tasks (Hackett and Betz 1981) and employees' confidence is another characteristic of a hospitality professional (Golubovskaya et al. 2017), self-efficacy is considered the third dispositional dimension of the proposed personology of a hospitality professional.

The critical review of the concepts of career commitment, career inheritance and selfefficacy was conducted to inform the proposed personology of a hospitality professional, further contextualized in the literature on professionalism, and to answer the research question of what makes a hospitality professional? For the purposes of this article, the origins 
of professionalism were first explored, leading to an understanding of this multidimensional concept as applied to less traditional occupations such as those in tourism and hospitality. It was established that professionalism has been more recently recognized as an ideology and a prerequisite for career success. Furthermore, the authors demonstrated that career commitment is a psychological contract between an individual and the hospitality career that s/he chooses, which is further strengthened by challenging work experience, positive professional development experiences, supportive organizational environment and interesting work (Sullivan et al. 1998). Career inheritance enables us to consider careers as being shaped by the family one was born into, and states that in the midst of making career decisions, individuals who are able to either accept or reject their hospitality career legacy become the most empowered (Inkson 2004). Thus, this concept helps us to conceptualize hospitality professionals as those for whom providing hospitality and being hospitable is a significant part of their professional identity. Self-efficacy, expressed as having confidence and beliefs in one's own capabilities, also plays a significant role in influencing one's career choices and behaviour, and becomes the third dimension of the proposed personology of a hospitality professional.

The purpose of the following section is to discuss each component of the personology of the hospitality professional, with clear links to the reviewed literature, and then explain the applicability of this framework to the hospitality industry.

\section{Discussion}

The purpose of this discussion chapter is to bring together the examined literature on hospitality environment, professionalism, self-efficacy, career inheritance and career commitment to explain the proposed personology of a hospitality professional. This 
framework can be further explained using the following illustrative representation of the interaction between the aforementioned five dimensions (Figure 1).

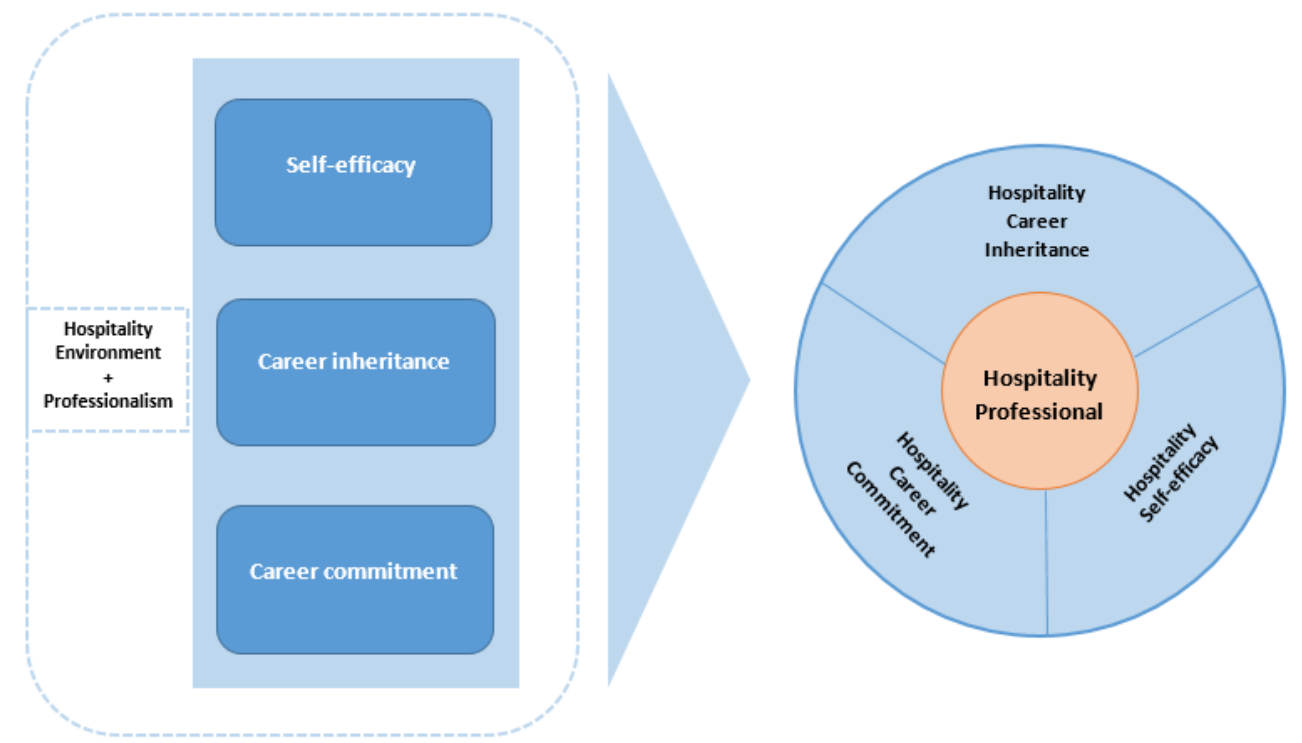

Figure 1: Proposed personology of a hospitality professional.

The hospitality environment has been identified as one that heavily relies on human capital and on the quality of its employees to deliver desired business outcomes (Cheng and Wong 2015; Baum 2015). As Lee (2014: 147) demonstrated 'the formation of a qualified and skilled workforce is a critical factor in any industry's growth and prosperity'. To ensure a stable workforce and increased career longevity among existing employees, their skills and professionalism need to be further considered (Poulston 2008; Maxwell et al. 2010; Mooney et al. 2016). This is particularly important in the industry, which is known for offering a hostile working environment and yet ample career opportunities both nationally and internationally. As highlighted by Baum (2015: 205) 'the quality of the people in the workplace can make a real and positive difference to business outcomes'. Thus, in this article 
the multidimensional concept of professionalism was examined as an overarching discourse defined through the lens of attitudinal dimensions (Lee 2014) to help us shed light on and deepen our understanding of what makes a hospitality professional? Despite the existing research on the non-industry specific characteristics of professionalism such as qualifications and development, competence and commitment (Burgess 2011), and those pertaining to professionalism within the hospitality industry such as passion, sensitivity and openmindedness to new trends, team-oriented attitude, competence and skills, emotional selfcontrol, professional ethics, leadership by example, and perfectionism (Cheng and Wong 2015: 122), this article focused on identifying the dispositional characteristics of a hospitality professional.

By reviewing the relevant literature on career commitment, career inheritance and selfefficacy, this article moves the conceptual discussion beyond core competencies of hospitality professionals or required technical skills and knowledge to proposing a personology of a hospitality professional founded on a unique interaction between the three concepts. What these concepts have in common is their affective nature, which corresponds with the nature of ideal hospitality as one that gives 'emotional satisfaction' to those practicing hospitableness (Blain and Lashley 2014: 4). Within the context of hospitality, the emotional attachment to one's hospitality career is very significant in helping to decide whether one wants to stay or leave that chosen career, and remains the strongest out of three the dimensions of career commitment discussed earlier (Meyer et al. 1993, 2002). Career inheritance or as conceptualized in this article, the hospitality career inheritance, is at the core of being hospitable and offering hospitality to others without any reciprocity (Telfer 2000). The nature of self-efficacy beliefs is based on affective states and it influences how individuals think, feel, act and behave (Bandura 1977, 1997). Furthermore, directing our attention to the psychological dimensions supports the conclusions reached by Teng (2008), 
who stated that research that considers efficacy beliefs in relation to career decision-making may also help to establish commitment towards the industry. This means that believing in one's own capabilities has implications beyond the proposed paradigm of personology, and can also help to explain how individuals choose to work in the hospitality industry as the context for their careers. Furthermore, within dimensions of professionalism suggested in various industries, according to the literature search conducted by Cheng and Wong (2015), commitment and self-confidence are listed and yet not accounted for in the most recent research. Having combined similar theories, Lee (2014: 142) brought together the literature on self-efficacy, service quality and proposed service quality efficacy, which 'refers to service provider's self-confidence regarding capabilities, skills, and expertise to effectively perform service tasks to meet customer expectations satisfactorily'. Furthermore, Golubovskaya et al. (2017) found that service skills and professional competencies become foundations for hospitable behaviour, which is dependent on employees' confidence, and build over time. Such hospitable behaviour is based on employees possessing intrinsic personality traits such as kindness, selflessness, generosity and the sense of being a host (Golubovskaya et al. 2017). 'Experienced professionals [...] know how to behave and also appear professionally. They know how to act, speak, and dress; they know how to act as professional [...]' (Noordegraaf 2007: 766). This implies that professionals understand the many dimensions that contribute to their professional demeanour, almost in the same way that a hospitable person is drawn more to types of work where they can welcome others and express their hospitality (Blain and Lashley 2014). Therefore, the proposed personology falls within the dispositional as opposed to trait-based characteristics of professionals (Lee 2014), which facilitates a more in-depth understanding of the individual person through the knowledge of the internal factors that impact on their behaviour (Baumgartner 2002). 
Based on the unique interaction between self-efficacy, career inheritance and career commitment, which is informed by the concept of professionalism and the nature of the hospitality environment discussed earlier, it is proposed that a personology of a hospitality professional consists of three dimensions: hospitality career commitment, hospitality career inheritance and hospitality self-efficacy (Figure 1). The remaining part of this discussion focuses on exploring these dimensions further.

A hospitality professional has high levels of hospitality self-efficacy, expressed as one's confidence to achieve a particular task or an outcome, in this case a successful hospitality career (Bandura 1986). He or she self-directs career paths by taking charge of career goals to improve skills, career prospects and achieve promotions (Gottfredson 1996). Such an individual is also willing to learn and treats challenges as obstacles to be overcome, rather than mere threats (Aryee and Tan 1992). Hospitality becomes an inherited part of their life and their career identity. This requires having the ability to thrive on the very nature of the industry, meaning dynamic, exciting and ever-changing (Inkson 2004). This is when the protean characteristics are being exercised, in particular the ability to be flexible and adaptable in the pursuit of career goals. Furthermore, Swailes (2003: 145) concludes that 'professionalism has much to do with the way in which work is done as much as identity with a profession or professional structure'. Thus, the inherited nature of hospitality is such a significant part of life for hospitality professionals that it becomes their second nature and represents the individual's ability to identify with hospitality beyond their working lives. This in turn is likely to compensate for working long hours, but also to contribute to the increased levels of hospitality career commitment. In times of increased changes in organizations, related to diversified workforce, globalization and technological advancements, having a career is likely to have a positive influence on individuals who are able to exercise the most control over this part of their working lives (Lent et al. 2002a, 2002b). In the industry known 
for its high staff turnover, a committed employee is an asset to both the organization and the industry. Diversity of roles, being challenged and using their skills is what may drive and motivate career-driven hospitality professionals to perform and develop an emotional attachment to their career. This requires a genuine understanding of the nature of hospitality, which is beyond the scope of this article but is proposed as an area of further research.

\section{Conclusion and future research}

The knowledge of key characteristics of individuals who choose hospitality as their career is of great importance to the hospitality industry, which has experienced challenges in recruiting future managers and retaining the skilled workforce.

This conceptual article shed more light on what makes a hospitality professional? by laying foundations for a personology of a hospitality professional through an exploration of the three interdisciplinary concepts namely, self-efficacy, career inheritance and career commitment within the context of the hospitality industry. Despite the industry preference to recruit staff on the basis of their competencies and task proficiency or specific technical expertise and job aptitude, this article focused on gaining insights into an individual person and the role that they play by focusing on dispositional as opposed to trait-based characteristics following the principles of personology by Murray (1981). Meanwhile professionalism was defined through the lens of attitudinal dimensions referring strictly to the characteristics of an individual (Hall 1968; Cheng and Wong 2015).

The proposed personology of a hospitality professional, which consists of three dimensions, hospitality career commitment, hospitality career inheritance and hospitality selfefficacy, was founded on the key principles of career commitment, career inheritance and self-efficacy (Figure 1). These, together with the concept of professionalism and the nature of the hospitality environment, form a wider theoretical landscape that underpins this 
personology. These dispositional characteristics of a hospitality professional transform one's understanding of individuals who chose hospitality as a career. Through this personology hospitality professionals can be seen as career-driven self-efficacious individuals, whose commitment to a hospitality career and the legacy of hospitality, expressed in practising hospitableness, make them an invaluable asset to any hospitality business. They tend to exhibit self-belief in their own capabilities and the ability for career self-management. Such career-driven hospitality professionals have high levels of confidence and treat challenges as obstacles to be overcome, rather than mere threats to their careers. Therefore the hospitality self-efficacy is one of the three dimensions of the proposed personology.

Passion for hospitality and being hospitable, which extend beyond the hospitality industry, together with the growing awareness of one's self-development are all conditions for a hospitality career inheritance. This next dimension of the proposed personology implies that hospitality is an inescapable part of one's life and becomes part of one's identity because of its inherited nature. Such legacy of hospitality is likely to have been passed from one's family and their commitment to hospitality. For others, the hospitality career inheritance is based on offering the ideal hospitality to everyone without the need for reciprocity.

An emotional attachment to one's career, ability to adapt and remain flexible when pursing career goals are derived from the concept of career commitment. Defined as a psychological state of a relationship between an individual and solely his or her career, this concept informs the hospitality career commitment, which implies that a hospitality professional develops an emotional bond to a chosen hospitality career that can withstand the less desirable aspects of hospitality work such as long working hours.

The knowledge of the personology of a hospitality professional has further implications for the human resource management in the hospitality industry. Together, the three dimensions are considered a strong predictor of one's desire to contribute to the successful performance 
of a hospitality business. Therefore, to meet the identified shortage of hospitality managers, the industry needs to attract hospitality professionals who are committed, emotionally attached to hospitality and exhibit high levels of self-confidence.

Future research should focus on conducting an exploratory study to determine the individual roles that these dimensions play towards a profile of a hospitality professional, and to establish whether this conceptualization can be applied to other professions. Furthermore, given the current lack of research on self-efficacy, career inheritance and career commitment, further research needs to demonstrate the extent to which they fully or partly explain the characteristics of a hospitality professional. Given the changing nature of the concept of career, which is no longer strictly defined by institutions of professions, future research should consider the meaning of career in the hospitality industry with a particular focus on including the concept of hospitality career inheritance. Also due to the global nature of hospitality and its multicultural workforce, what role might culture play in informing the proposed personology and understanding of professionalism? Finally, as Evetts (2003: 407) concluded 'the meaning of professionalism is not fixed'; exploring how professionalism is understood and defined by hospitality professionals could shed light on new interpretations of this complex concept and be used to promote hospitality careers as desired and with a professional status.

To attract individuals with these desired characteristics, improve the results of the recruitment and selection process and to validate the proposed framework, life history is the recommended methodological lens for primary data collection. It allows for an in-depth analysis of individuals' lives and their career-related choices, and becomes a window into understanding how the past has shaped life and career choices leading up to the present (Atkinson 2002; Goodson and Phillimore 2004; Ladkin 2004). Semi-structured interviews are considered one of the most effective research methods to capture the subjective nature of 
processes that influence one's behaviour, whilst giving potential participants the opportunity to elaborate on experiences they judge as the most important to them (Warren 2002; Usher and Pajares 2008). This methodology aligns with the original concept of personology, which calls for understanding individuals' behaviour through the analysis of the influence of the past, present and future on their personality (Schultz and Schultz 2009), drawing on Murray's approach to personality and personality assessment (Murray 1981). Further research should also be conducted to devise a set of interview questions based on the three concepts to yield better recruitment and selection outcomes whilst contributing to the scarcity of knowledge on what being a hospitality professional really entails.

\section{References}

Aryee, S. and Tan, K. (1992), 'Antecedents and outcomes of career commitment', Journal of Vocational Behavior, 40:3, pp. 288-305.

Atkinson, R. (2002), 'The life story interview', in J. F. Gubrium and J. A. Holstein (eds), Handbook of Interview Research: Context and Method, Thousand Oaks: Sage, pp. 121-40.

Ballout, H. I. (2009), 'Career commitment and career success: Moderating role of selfefficacy', Career Development International, 14:7, pp. 655-670.

Bandura, A. (1977), Social Learning Theory, New York: General Learning Press. (1986), Social Foundations of Thought and Action: A Social Cognitive Theory, Englewood Cliffs: Prentice-Hall. 
(1997), 'Self-efficacy', Harvard Mental Health Letter, 13:9, pp. 4-7.

(1998), 'Personal and collective efficacy in human adaptation and change', in J. G.

Adair, D. Belanger and K. L. Dion (eds), Advances in Psychological Science, Personal, Social and Cultural Aspects, vol. 1: Hove: Psychology Press, pp. 51-71.

Barnett, B. R. and Bradley, L. (2007), 'The impact of organizational support for career development on career satisfaction', Career Development International, 12:7, pp. 617-36.

Barron, P., Broadbridge, A., Maxwell, G. and Ogden, S. (2007), 'Careers in hospitality management: Generation Y's experiences and perceptions', Journal of Hospitality and Tourism Management, 14:2, pp. 119-28.

Baum, T. (2015), 'Human resources in tourism: still waiting for change? - a 2015 reprise', Tourism Management, 50:4, pp. 204-12.

Baumgartner, H. (2002), 'Toward a personology of the consumer', Journal of Consumer Research, 29:2, pp. 286-92.

Bharwani, S. and Jauhari, V. (2013), 'An exploratory study of competencies required to cocreate memorable customer experiences in the hospitality industry', International Journal of Contemporary Hospitality Management, 25:6, pp. 823-43. 
Birkett, R. (2008), 'The hospitality industry is missing out on young talent, warns BHA', The Caterer, 7 October, https://www.thecaterer.com/articles/323884/the-hospitality-industry-ismissing-out-on-young-talent-warns-bha Accessed 19 June 2012.

Blain, M. and Lashley, C. (2014), 'Hospitableness: The new service metaphor? Developing an instrument for measuring hosting', Research in Hospitality Management, 4:1\&2, pp. 1-8.

Blau, G. J. (1985), 'The measurement and prediction of career commitment', Journal of Occupational Psychology, 58:4, pp. 277-88.

(1988), 'Further exploring the meaning and measurement of career commitment', Journal of Vocational Behavior, 32:3, pp. 284-97.

British Hospitality Assosiation (2017), 'Economic contribution of UK hospitality industry', http://www.bha.org.uk/. Accessed 2 Febraury 2017.

Brotherton, B. and Wood, R. C. (2000), 'Hospitality and hospitality management', in C. Lashley and A. Morrison (eds), In Search of Hospitality Theoretical Perspectives and Debates, Oxford: Butterworth-Heinemann, pp. 134-56.

Burgess, C. (2011), 'Are hotel managers becoming more professional: The case of hotel financial controllers?', International Journal of Contemporary Hospitality Management, 235, pp. 681-95. 
Burke, N. J., Bird, J. A., Clark, M. A., Rakowski, W., Guerra, C., Barker, J. C. and Pasick, R. J. (2009), 'Social and cultural meanings of self-efficacy', Health Education \& Behavior, 36:1, pp. 111S-28S.

Cassel, S. H., Thulemark, M. and Duncan, T. (2018), 'Career paths and mobility in the Swedish hospitality sector', Tourism Geographies, 20:1, pp. 29-48.

Chen, S. L. M., Jang, S. C., and Hu, C. (2005), 'Service quality gap analysis toward customer loyalty: Practical guidelines for casino hotels', International Journal of Hospitality Management, 24:3, pp. 465-72.

Cheng, S. and Wong, A. (2015), 'Professionalism: A contemporary interpretation in hospitality industry context', International Journal of Hospitality Management, 50:1, pp. $122-33$.

Cherian, J. and Jacob, J. (2013), 'Impact of self efficacy on motivation and performance of employees', International Journal of Business and Management, 8:14, pp. 80-88.

Cherniss, C. (1991), 'Career commitment in human service professionals: A biographical study', Human Relations, 44:5, pp. 419-37.

Choi, B. Y., Park, H., Yang, E., Lee, S. K., Lee, Y. and Lee, S. M. (2012), 'Understanding career decision self-efficacy: A meta-analytic approach', Journal of Career Development, 39:5, pp. 443-60. 
Choi, K. and Kim, D.-Y. (2013), 'A cross cultural study of antecedents on career preparation behavior: Learning motivation, academic achievement, and career decision self-efficacy', Journal of Hospitality, Leisure, Sport \& Tourism Education, 13:1, pp. 19-32.

Cockburn-Wootten, C. (2012), 'Critically unpacking professionalism in hospitality: Knowledge, meaningful work and dignity', Hospitality \& Society, 2:2, pp. 215-30.

Colarelli, S. M. and Bishop, R. C. (1990), 'Career commitment: functions, correlates, and management', Group \& Organization Management, 15:2, pp. 158-76.

Cooper-Hakim, A. and Viswesvaran, C. (2005), 'The construct of work commitment: An integrative framework', Psychological Bulletin, 131:2, pp. 241-59.

Dhir, L. A. (2013), 'Top ten traits of a hospitality professional', eHotelier, http://ehotelier.com/insights/2013/07/17/top-ten-traits-of-a-hospitality-professional/. Accessed 27 April 2017.

Evetts, J. (2003), 'The sociological analysis of professionalism', International Sociology, $18: 2,395-415$. (2011), ‘A new professionalism? Challenges and opportunities', Current Sociology, 59:4, pp. 406-22.

Goodale, J. G. and Hall, D. T. (1976), 'Inheriting a career: The influence of sex, values, and parents", Journal of Vocational Behavior, 8:1, pp. 19-30. 
Goodson, L. and Phillimore, J. (2004), 'The inquiry paradigm in qualitative tourism research', in J. Phillimore and L. Goodson (eds), Qualitative Research in Tourism. Ontologies, Epistemologies and Methodologies, London: Routledge, pp. 30-45.

Gottfredson, L. S. (1996), 'Gottfredson' theory of circumscription and compromise', in D. Brown and L. Brooks (eds), Career Choice and Development, 3rd ed., San Francisco: JosseyBass, pp. 179-232.

_ (2002), 'Gottfredson's theory of circumscription, comprise and self-creation', in D.

Brown and L. Brooks (eds), Career Choice and Development, 3rd ed., San Francisco: JosseyBass, pp 85-148.

_ (2005), 'Applying Gottfredson's theory of circumscription and compromise in career guidance and counselling', in S. D. Brown and R. W. Lent (eds), Career Development and Counselling: Putting Theory and Research to Work, Hoboken: John Wiley, pp. 71-100.

Golubovskaya, M., Robinson, R. N. S. and Solnet, D. (2017), 'The meaning of hospitality: Do employees understand?', International Journal of Contemporary Hospitality Management, 29:5, pp. 1282-304.

Goulet, L. R. and Singh, P. (2002), 'Career commitment: A reexamination and an extension', Journal of Vocational Behavior, 61:1, pp. 73-91. 
Graham, S. and Weiner, B. (1996), 'Theories and principles of motivation', in D. C. Berliner, and R. C. Calfee (eds), Handbook of Educational Psychology, New York: Simon \& Schuster, pp. 63-84.

Hackett, G. and Betz, N. E. (1981), 'A self-efficacy approach to the career development of women', Journal of Vocational Behavior, 18:3, pp. 326-39.

Hall, R. H. (1968), 'Professionalism as enterprise: Service class politics and the redefinition of professionalism, Sociology, 32:1, pp. 43-63.

Hall, D. T. (2004), 'The protean career: A quarter-century journey", Journal of Vocational Behavior, 65:1, pp. 1-13.

Haven-Tang, C. and Jones, E. (2008), 'Labour market and skills needs of the tourism and related sectors in Wales', International Journal of Tourism Research, 10:4, pp. 353-63.

Helsby, G. (1996), 'Professionalism in English secondary schools', Journal of Education for Teaching, 22:2, pp. 135-48.

Higgins, M. C., Dobrow, S. R. and Chandler, D. (2008), 'Never quite good enough: The paradox of sticky developmental relationships for elite university graduates', Journal of Vocational Behavior, 72:2, pp. 207-24.

Hjalager, A.-M. and Andersen, S. (2001), 'Tourism employment: Contingent work or professional career?', Employee Relations, 23:2, pp. 115-29. 
Hospitality Guild (2013), 'What Is hospitality?', http://www.hospitalityguild.co.uk/A-Careerin-Hospitality/The-industry. Accessed 16 April 2013.

Hussey, J., Holden, M. T. and Lynch, P. (2010), 'Defining professionalism in the tourism context', Tourism and Hospitality Research in Ireland Conference (THRIC), Shannon Hotel School, Co Clare, Ireland, 6 June.

Inkson, K. (2004), 'Images of career: Nine key metaphors', Journal of Vocational Behavior, 65:1, pp. 96-111.

(2007), Understanding Careers: The Metaphors of Working Lives, London: Sage.

Johns, N. and McKechnie, M. (1995), 'Career demands and learning perceptions of hotel and catering graduates- ten years on', International Journal of Contemporary Hospitality Management, 7:5, pp. 9-12.

Kaufman, T. J and Ricci, P. (2014), 'Creation of a professionalism scale for hospitality students: An exploratory study', SAGE Open, 4:4, pp. 1-4.

King, B., McKercher, B. and Waryszak, R. (2003), 'A comparative study of hospitality and tourism graduates in Australia and Hong Kong', International Journal of Tourism Research, 5:6, pp. 409-20. 
Kong, H., Cheung, C. and Song, H. (2011), 'Hotel career management in China: Developing a measurement scale', International Journal of Hospitality Management, 30:1, pp. 112-18.

Ko, W. H. (2012), 'The relationships among professional competence, job satisfaction and career development confidence for chefs in Taiwan', International Journal of Hospitality Management, 31:3, pp. 1004-11.

Kwok, L., Adams, C. and Feng, D. (2012), 'A comparison of graduating seniors who receive job offers and those who do not according to hospitality recruiters' selection criteria', International Journal of Hospitality Management, 31:2, pp. 500-10.

Ladkin, A. (2002), 'Career analysis: A case study of hotel general managers in Australia', Tourism Management, 23:4, pp. 379-88.

(2004), 'The life and work history methodology: A discussion of its potential use for tourism and hospitality research', in J. A. Phillimore and L. Goodson (eds), Qualitative Research in Tourism: Ontologies, Epistemologies, Methodologies, London: Routledge, pp. $236-54$.

Ladkin, A. and Weber, K. (2010), 'Career aspects of convention and exhibition professionals in Asia', International Journal of Contemporary Hospitality Management, 22:6, pp. 871-86.

Law, B. (1981), 'Community interaction: A 'mid-range' focus for theories of career development in young adults', British Journal of Guidance \& Counselling, 9:2, pp. 142-158. 
Lee, K-J. (2014), 'Attitudinal dimensions of professionalism and service quality efficacy of frontline employees in hotels', International Journal of Hospitality Management, 41:1, pp. $140-48$.

Lent, R. W., Brown, S., D. and Hackett, G. (2002a), 'Social cognitive career theory', in D. Brown (ed.), Career Choice and Development, 4th ed., San Francisco: Wiley, pp. 255-311.

Lent, R. W., Brown, S. D., Talleyrand, R., McPartland, E. B., Davis, T., Chopra, S. B., Alexander, M. S., Suthakaran, V. and Chai, C.-M. (2002b), 'Career choice barriers, supports, and coping strategies: College students' experiences', Journal of Vocational Behavior, 60:1, pp. 61-72.

Maddux, J. E. (2002), 'Self-efficacy: The power of believing you can', in C. R. Snyder and S. J. Lopez (eds), Handbook of Positive Psychology, Oxford: Oxford University Press, pp. 27787.

Mak, A. H. N., Wong, K. K. F. and Chang, R. C. Y. (2011), 'Critical issues affecting the service quality and professionalism of the tour guides in Hong Kong and Macau', Tourism Management, 32:6, pp. 1142-452.

Maxwell, G. A., Ogden, S. M. and Broadbridge, A. (2010), 'Generation Y's career expectations and aspirations: Engagement in the hospitality industry', Journal of Hospitality and Tourism Management, 17:1, pp. 53-61. 
Meyer, J. P. and Allen, N. J. (1984), 'Testing the "side-bet theory" of organizational commitment: Some methodological considerations', Journal of Applied Psychology, 69:3, pp. $372-78$.

Meyer, J. P. and Herscovitch, L. (2001), 'Commitment in the workplace: Toward a general model', Human Resource Management Review, 11:3, pp. 299-326.

Meyer, J. P., Allen, N. J. and Smith, C. A. (1993), 'Commitment to organizations and occupations: Extension and test of a three-component conceptualization', Journal of Applied Psychology, 78:4, pp. 538-51.

Meyer, J. P., Stanley, D. J., Herscovitch, L. and Topolnytsky, L. (2002), ‘Affective, continuance, and normative commitment to the organization: A meta-analysis of antecedents, correlates, and consequences', Journal of Vocational Behavior, 61:1, pp. 20-52.

Michel, J. W., Kavanagh, M. J. and Tracey, J. B. (2013), 'Got support? The impact of supportive work practices on the perceptions, motivation, and behavior of customer-contact employees', Cornell Hospitality Quarterly, 54:2, pp. 161-173.

Mooney, S. K., Harris, C. and Ryan, I. (2016), 'Long hospitality careers - a contradiction in terms?', International Journal of Contemporary Hospitality Management, 28:11, pp. 2589608. 
Mullen, R. (2016), 'How to tackle employee turnover and retain your staff', The Caterer, 23

November, https://www.thecaterer.com/articles/369298/how-to-tackle-employee-turnoverand-retain-your-staff. Accessed 15 November 2017.

Murray, H. A. (1981), Endeavors in Psychology: Selections from the Personology of Henry A. Murray, New York: Harper \& Row.

Niu, H.-J. (2010), 'Investigating the effects of self-efficacy on foodservice industry employees' career commitment', International Journal of Hospitality Management, 29:4, pp. $743-50$.

Noordegraaf, M. (2007), 'From “pure” to "hybrid” professionalism: Present-day professionalism in ambiguous public domains', Administration and Society, 39:6, pp. 76185.

O’Leary, S. and Deegan, J. (2005), 'Career progression of Irish tourism and hospitality management graduates', International Journal of Contemporary Hospitality Management, $17: 5$, pp. 421-32.

Oxford Economics (2015), The Economic Contribution of the UK Hospitality Industry, Oxford: British Hospitality Association.

Paraskevas, A. (2001), 'Internal service encounters in hotels: an empirical study', International Journal of Contemporary Hospitality Management, 13:6, pp. 285-92. 
Patton, W. and McMahon, M. (2006), Career Development and Systems Theory, 2nd. ed., Rotterdam: Sense Publishers.

People 1st (2013), State of the Nation Report 2013: An Analysis of Labour Market Trends, Skills, Education and Training within the UK Hospitality and Tourism Industries, Uxbridge: People 1st.

Pizam, A. (2007), 'Educating the next generation of hospitality professionals', International Journal of Hospitality Management, 26:1, pp. 1-3.

Poulston, J. (2008), 'Hospitality workplace problems and poor training: A close relationship', International Journal of Contemporary Hospitality Management, 20:4, pp. 412-27.

Ruetzler, T., Taylor, J., Reynolds, D. and Baker, W. (2011), 'Understanding perceptions of professional attributes using conjoint analysis', International Journal of Hospitality Management, 30:3, pp. 551-57.

Schultz, D. P. and Schultz, S. E. (2009), Theories of Personality, 9th ed., Belmont: Cengage Learning.

Sisson, L. G. and Adams, A. R. (2013), 'Essential hospitality management competencies: The importance of soft skills', Journal of Hospitality and Tourism Education, 25:3, pp. 131-45.

Stolorow, R. D. (2012), 'Toward a renewal of personology in psychotherapy research', Psychotherapy, 49:4, pp. 471-72. 
Suh, E., West, J. J. and Shin, J. (2012), 'Important competency requirements for managers in the hospitality industry', Journal of Hospitality, Leisure, Sport and Tourism Education, 11:2, pp. 101-12.

Sullivan, S. E. (1999), 'The changing nature of careers: A review and research agenda', Journal of Management, 25:3, pp. 457-84.

Sullivan, S. E., Carden, W. A. and Martin, D. F. (1998), 'Careers in the next millennium: Directions for future research', Human Resource Management Review, 8:2, pp. 165-85.

Swailes, S. (2003), 'Professionalism: Evolution and measurement', The Service Industries Journal, 23:2, pp. 130-49.

Swanson, J. L. and Fouad, N. A. (2010), Career Theory and Practice: Learning through Case Studies, 2nd ed., London: Sage.

Taylor, K. M. and Betz, N. E. (1983), 'Applications of self-efficacy theory to the understanding and treatment of career indecision', Journal of Vocational Behavior, 22:1, pp. $63-81$.

Telfer, E. (2000), ‘The philosophy of hospitableness', in C. Lashley and A. Morrison (eds), In Search of Hospitality: Theoretical Perspectives and Debates, Oxford: ButterworthHeinemann, pp. 38-55. 
Tesone, D. and Ricci, P. (2006), ‘Toward a definition of entry-level job competencies: Hospitality manager perspectives', International Journal of Hospitality \& Tourism Administration, 7:4, pp. 65-80.

UKHospitality (2019), 'Industry focus', https://www.ukhospitality.org.uk/ Accessed 05 April 2019.

Usher, E. L. (2009), 'Sources of middle school students' self-efficacy in mathematics: A qualitative investigation', American Educational Research Journal, 46:1, pp. 275-314.

Usher, E. L. and Pajares, F. (2008), 'Sources of self-efficacy in school: Critical review of the literature and future directions', Review of Educational Research, 78:4, pp. 751-96.

Vance, R. J. (2006), Employee Engagement and Commitment: The Guide to Understanding, Measuring and Increasing Engagement in Your Organisation, Alexandria, VA: SHRM Foundation.

Walmsley, A. (2011), CHME Report on Hospitality Higher Education in the UK, 2011, London: Council for Hospitality Management Education.

Walsh, K. and Taylor, M. S. (2007), 'Developing in-house careers and retaining management talent: What hospitality professionals want from their jobs', Cornell Hotel and Restaurant Administration Quarterly, 48:2, pp. 163-82. 
Wang, Y.-F. (2013), 'Constructing career competency model of hospitality industry employees for career success', International Journal of Contemporary Hospitality Management, 25:7, pp. 994-1016.

Warren, C. A. B. (2002), 'Qualitative interviewing', in J. F. Gubrium and J. A. Holstein (eds), Handbook of Interview Research: Context and Method, Thousand Oaks: Sage, pp. 83101.

Wilensky, H. L. (1964), 'The professionalisation of everyone?', The American Journal of Sociology, 70:2, pp. 137-58.

World Travel and Tourism Council (WTTC) (2015), '14 million jobs at risk due to global travel and tourism talent shortage', https://www.wttc.org/media-centre/press-releases/pressreleases/2015/14-million-jobs-at-risk-due-to-global-travel-tourism-talent-shortage/. Accessed 8 November 2017.

(2017), World Travel and Tourism Economic Impact 2017, London: World Travel and Tourism Council, https://www.wttc.org/-/media/files/reports/economic-impactresearch/regions-2017/world2017.pdf Accessed 8 November 2017.

\section{Contributor details}

Dr Maria Gebbels, MIH, is a senior lecturer at the University of Greenwich. She was awarded a Ph.D. for a study entitled, 'Career paths in hospitality: A life history approach' at the University of Brighton. Maria is in the editorial board for Hospitality Quarterly, the Institute of Hospitality's magazine and on the executive board for the Council for Hospitality 
Management Education (CHME). Her research interests are career development studies, critical hospitality management research and life history methodology. She is currently working on understanding the factors that enable women to progress to senior management roles in the hospitality industry. Besides her work in academia, Maria had worked in the hospitality industry for ten years in management roles in various sectors of the industry.

Dr Pantelidis, FIH, is Chair of the Council for Hospitality Management Education and a principal lecturer at the University of Brighton. He is a Hospitality Action Guardian and has served on the Executive Board of the Institute of Hospitality and on the boards of three more charities. He is the Hospitality Editor for Tourism and Hospitality Research (Sage publications) and in the editorial board of four more journals, and a speaker for industry expos and conferences and a hospitality consultant with proven track record. Prior to his academic career he worked for hotel \& restaurant companies in Europe, hence his preference for applied research that focuses on hotel and food and beverage technology, machine learning, Big Data and online consumer behaviour.

Dr Steven Goss-Turner is honorary research fellow and former Head of Operations for the School of Sport and Service Management at the University of Brighton. Steven has an MSc in Human Resource Development from the University of Portsmouth and was awarded a Ph.D. for a study entitled, 'The relationship between organizational culture and labour turnover'. Before his academic career, he spent eighteen years with the then Trusthouse Forte Hotels, latterly as Training Director for the London and International division. He is co-author of 
Human Resource Management in the Hospitality Industry, the 10th edition of which will be published later in 2019.

Contact:

University of Greenwich, Department of Marketing, Events and Tourism, Old Royal Naval College

Park Row, London SE10 9LS, UK.

E-mail: m.m.gebbels@greenwich.ac.uk

ORCID: 0000-0001-9623-2655

Pantelidis and Steven Goss-Turner University of Brighton, School of Sport and Service Management, Darley Road, Eastbourne BN20 7UR, UK.

E-mail: isp12@brighton.ac.uk

ORCID: 0000-0003-4562-2893

E-mail: sgossturner@gmail.com

ORCID: 0000-0003-0648-175X 